\title{
INITIAL EXPERIENCE WITH STAPLED HEMORRHOIDOPEXY FOR TREATMENT OF HEMORRHOIDS
}

\author{
Carlos Walter SOBRADO, Guilherme Cutait de Castro COTTI, \\ Fabricio Ferreira COELHO and Júlio Rafael Mariano da ROCHA
}

\begin{abstract}
Background - Introduction of stapled hemorrhoidopexy by Longo in 1998 represented a radical change in the treatment of hemorrhoids. By avoiding multiple excisions and suture lines in the perianal region, stapled hemorrhoidopexy is intended to offer less postoperative pain than with conventional techniques. Objective - To report and analyze the intra and postoperative results gained during initial experience with stapled hemorrhoidopexy. Methods - One hundred and fifty five patients (67 males) with average age of 39.5 years (21-67 years) underwent stapled hemorrhoidopexy between June 2000 and December 2003 with symptomatic third-degree $(\mathrm{n}=74)$ and fourth-degree $(\mathrm{n}=81)$ hemorrhoids. Mean follow-up period was 20 months (14-60 months). Results - Preoperative symptoms were prolapse (96.7\%) and anal bleeding (96.1\%). Overall mean operative time was 23 minutes (16-48 minutes). We observed one case of stapler failure and one case of failure to introduce the stapler occurred in a patient with previous anal surgery. Additional sutures for hemostasis were required in 103 patients (66.5\%). Resection of skin tags was performed in 45 cases (29\%). Postoperatively scheduled analgesia with oral dipyrone and celecoxib was enough for pain control in 131 patients (84.5\%). Rescue analgesia was necessary in 24 cases $(15.5 \%)$. Five patients needed opiates for pain control. Hospital discharge took place on the first postoperative day in 140 patients $(90.3 \%)$. First defecation without pain was reported by 118 patients $(76.1 \%)$. Postoperative complications were anal bleeding (10.3\%), severe pain (3.2\%), urinary retention (3.9\%), fever without any signs of perianal infection $(1.9 \%)$, incontinence for flatus $(1.9 \%)$, hemorrhoidal thrombosis (1.3\%). Two patients presented symptoms of recurrent hemorrhoidal disease and were successfully treated by conventional hemorrhoidectomy. They were no cases of anal stenosis, permanent incontinence, chronic pain or deaths in this series. Conclusions - Hemorrhoidopexy can be considered a feasible and safe alternative technique to conventional hemorroidectomy for select patients.
\end{abstract}

HEADINGS - Postoperative complications. Postoperative pain. Hemorrhoids. Anorectal surgery. Surgical staplers.

\section{INTRODUCTION}

Despite the major advances that have occurred in the treatment of colorectal diseases, there have been few modifications in the management of hemorrhoidal disease in the last decades. Traditionally, first and second-degree hemorrhoids are treated by dietary modifications and nonoperative techniques such as rubber band ligation, infrared photocoagulation and sclerotherapy ${ }^{(8,15,22,24,25)}$. Operative treatment has been reserved for advanced hemorrhoidal disease (third and fourth-grade) and comprehends excision of the hemorrhoidal tissue ${ }^{(8,15,20,21,25)}$. The most frequent surgical procedures performed are the Milligan-Morgan and Ferguson techniques, both of which are associated with low complications and excellent results in terms of relief of symptoms, but severe pain may arise postoperatively due to removal of innervated anoderm below the dentate line and perianal skin $^{(8,9,15,21)}$.

Several modifications to conventional techniques have been proposed aiming to reduce postoperative pain including lateral internal sphincterotomy, anal dilatation, diathermy hemorrhoidectomy and use of anal sphincter relaxants or metronidazole ${ }^{(2,16,20,23,25)}$. However, none have resulted in a significant decrease in postoperative pain to gain universal acceptance ${ }^{(3)}$.

Once again, in the past few years, a great debate has arisen about the surgical management of hemorrhoids, due to the introduction of a new technique for management of advanced hemorrhoidal disease called procedure for prolapse and hemorroidopexy (PPH) technique, or stapled hemorrhoidopexy. Introduced by $\mathrm{LONGO}^{(12)}$ in 1998, it uses a circular stapler to excise a complete circular strip

Disciplines of Digestive Surgery and Coloproctology, São Paulo University Medical School, São Paulo, SP, Brazil.

Address for correspondence: Dr. Carlos Walter Sobrado - Rua Itapeva, 500 - $7^{\circ}$ andar — cj. B - 01332-000 - São Paulo, SP, Brasil. E-mail: sobrado@iconet.com.br 
of rectal mucosa above the dentate line which lifts the prolapsed hemorrhoidal tissue, removing the redundant mucosa and stapling off the end branches of the superior hemorrhoidal artery ${ }^{(5,12)}$. By avoiding multiple excisions and suture lines on the sensitive anal mucosa below the dentate line, the initial experience of several authors has shown that pain appears to be far less with PPH than with conventional techniques ${ }^{(8,10,11,15,24,25)}$.

The results of stapled hemorrhoidopexy have been assessed in some randomized controlled trials ${ }^{(7,10,11,16,19,24)}$. These studies have consistently shown a decrease in postoperative pain, analgesic requirement, length of surgical procedure, short recovery time and early return to normal activities. The complications and postoperative recurrence rates are similar to those reported after excisional technique ${ }^{(7,9,11,16)}$.

Assessment of long-term results and complications of the operation remains unknown, several studies reported chronic postoperative pain $^{(4)}$,recurrent prolapse $\mathrm{e}^{(9,16)}$ and anal stenosis ${ }^{(6,18)}$ but findings in other studies suggest there are no significant differences between stapled hemorrhoidopexy and conventional hemorrhoidectomy in terms of quality of life and functional outcomes ${ }^{(1,20)}$.

The purpose of the present study is to report the prospective data regarding our initial experience with stapled hemorrhoidopexy, comparing the results with those published in the literature.

\section{PATIENTS AND METHOD}

Between June 2000 and December 2003, 155 consecutive patients with symptomatic third-degree and fourth-degree hemorrhoids were included in this study (Figure 1). All patients were informed about the technique performed preoperatively. The operation was performed by a single experienced colorectal surgeon (CWS).

Preoperative evaluation included a medical history, physical and proctological examinations, and routine laboratorial tests in

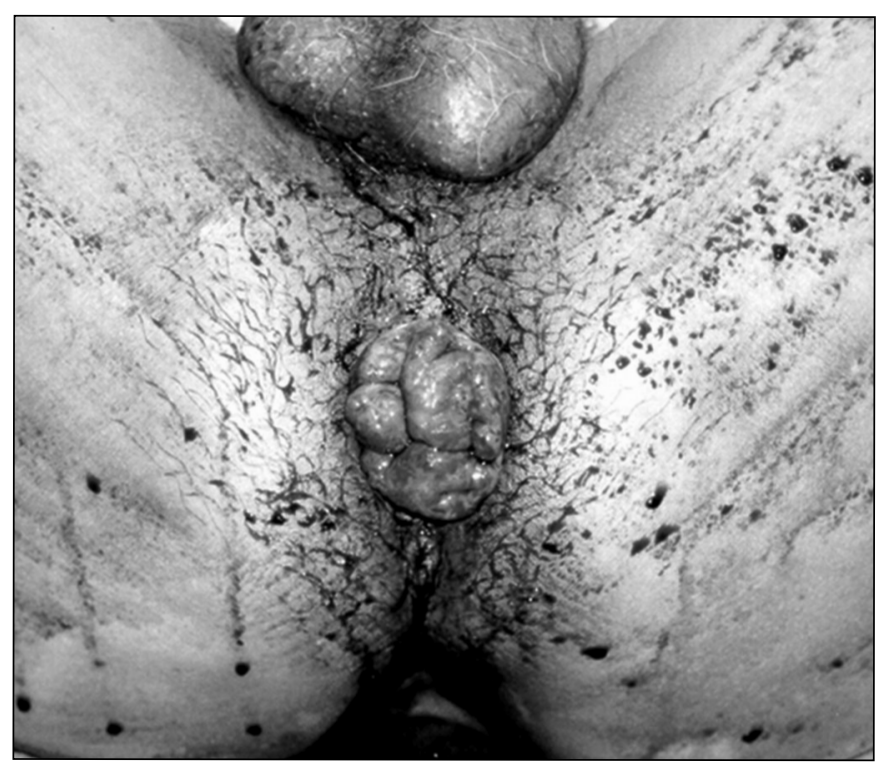

FIGURE 1 - Pre-operative aspect of a patient with third-degree hemorrhoids all patients. Patients over 45 underwent cardiologic evaluation preoperatively. Colonoscopy was performed preoperatively for patients with important changes in bowel habit, a previous history of colorectal cancer or polyps and for all patients over 50 . Exclusion criteria included coagulopathy and patients receiving treatment with oral anticoagulants and other associated anorectal diseases (condyloma, fistula, abscess, fissura).

Operations were performed without bowel preparation and all patients were given $2 \mathrm{~g}$ of cefoxitin, at the time of the anesthesia. Surgery was performed either under general anesthesia (56 patients $-36.1 \%$ ) or spinal anesthesia (99 patients - 63.9\%). A chronometer measured operative time.

Patients were operated in lithotomy position and the technique used in all procedures was that reported by $\mathrm{LONGO}^{(12)}$. A circular anal dilatator (CAD33; Ethicon Endo-Surgery, Cincinatti, OH, USA) was introduced after manual reduction of the prolapse of the anoderm and parts of the anal mucous membrane. After removal of the obturator, the prolapsed mucous membrane falls into the lumen of the circular anal dilator. Then, a 0 polypropylene endoanal purse-string suture was placed circumferentially $4 \mathrm{~cm}$ above the dentate line encompassing mucosa and submucousa through the window of the anoscope (PSA33; Ethicon EndoSurgery, Cincinatti, OH, USA). The hemorrhoidal circular stapler (HCS33; Ethicon Endo-Surgery, Cincinatti, OH, USA) was introduced through the anus, the purse-string suture tied down onto the shaft of the instrument. The instrument was closed and fired thus incorporating the mucosal tissue in the pursestring within the head of the gun. The circular knife excised the redundant tissue and the anastomosis was accomplished by a double row of titanium staples. The instrument was kept closed for 30 seconds to help achieve hemostasis. The staple line was inspected and, when necessary, additional hemostatic suture with 3-0 polyglecaprone on a $25 \mathrm{~mm}$ curved needle was performed. If prominent skin tags were present at the time of surgery, they

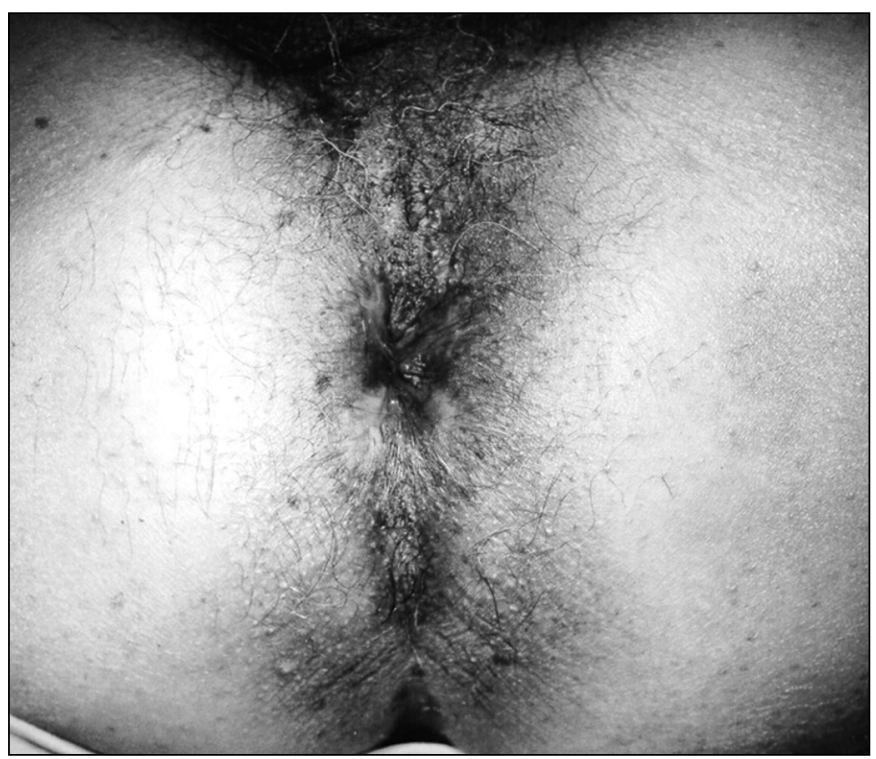

FIGURE 2 - Immediate postoperative result after stapled hemorrhoidopexy of the same patient 
were resected. Figure 2 illustrates the immediate postoperative result after the stapled hemorrhoidopexy. The excised tissue was sent for histopathological examination in all cases.

During hospital stay, a dietician evaluated all patients to ensure they received 20-30 mg of additional fiber supplements (administered as Psyllium) and at least 2 liters of water/day postoperatively. Dimethicone was also administered for the first 5 postoperative days. Postoperative analgesia consisted of dipyrone ( $1 \mathrm{~g} /$ orally four times daily) and celecoxib (200 mg/orally twice a day). Analgesia was suspended on the third to fifth postoperative days, or when the patient referred defecation without pain. When necessary, intramuscular cetoprofen ( $100 \mathrm{mg}$ twice a day) or oral oxycodone $20 \mathrm{mg}$ was administered as rescue analgesia.

Patients were discharge from the hospital on the first postoperative day or later if rescue analgesia was necessary. Clinical evaluations, including complete proctological examination, were routinely repeated at postoperative days 5 to 7,3 weeks and 6 months after surgery.

Preoperative data included demographic characteristics, symptoms of hemorrhoidal disease and anal continence. Operative data evaluated were type of anesthesia, patient position, operative time, distance from the stapling to the dentate line, need for complementary hemostasis, associated procedures and any unexpected events. Postoperative outcomes included postoperative pain, frequency of rescue analgesia, characteristics of the first defecation, control of hemorrhoidal symptoms, frequency of hemorrhoid recurrence, fecal incontinence, resume of normal activities, and all kinds of complications.

\section{RESULTS}

A total of 155 patients operated between June 2000 and December 2003 with symptomatic third-degree $(\mathrm{n}=74)$ and fourth-degree $(n=81)$ hemorrhoids were included in this study, with 67 males and 88 females. Average age was 39.5 years (range 21-67 years). Mean follow-up period was 20 months (range 14 to 60 months). Demographic data are show in Table 1.

Preoperative symptoms were prolapse $(\mathrm{n}=150-96.7 \%)$, anal bleeding $(n=149-96.1 \%)$, anal discomfort $(n=99-64 \%)$ and anal itching $(\mathrm{n}=70-45 \%)$. Associated skin tags were detected in 45 patients $(29 \%)$.

All patients were operated in lithotomy position and surgery was performed under general anesthesia in 56 patients (36.1\%) and spinal anesthesia in $99(63.9 \%)$.

TABLE 1 - Baseline characteristics of patients

\begin{tabular}{lcc}
\hline Characteristic & Number (n) & $\%$ \\
\hline Male & 67 & 43.2 \\
Female & 88 & 56.8 \\
Degree of hemorrhoids & & \\
$\quad$ Third & 74 & 47.7 \\
$\quad$ Fourth & 81 & 52.3 \\
Mean age (range) years & $39.5(21-67)$ & - \\
Total of patients & 155 & 100 \\
\hline
\end{tabular}

Mean operative time was 23 minutes (16 to 48 minutes). The suture line was performed $4.0 \mathrm{~cm}$ above the dentate line. One case of stapler failure resulted, due to an interruption in the posterior titanium staples. A manual suture with 0 polyglecaprone successfully corrected it. Failure to introduce the stapler occurred in a patient with previous anal surgery.

Additional sutures for hemostasis were required in 103 patients $(66.5 \%)$. Resection of skin tags while undergoing PPH was performed in 45 cases $(29 \%)$. Small residual prolapsed mucosa were detected below the suture line in 18 patients $(11,6 \%)$ and were treated with an additional 3.0 polyglecaprone manual suture.

Postoperatively scheduled analgesia with oral dipyrone and celecoxib was enough for pain control in 131 patients $(84.5 \%)$. Rescue analgesia was necessary in 24 cases (15.5\%). Five patients $(3.2 \%)$ needed opiates for pain control. Analgesic usage decreased over time and by the fifth postoperative day, almost all patients were not requiring analgesics.

Hospital discharge took place on the first postoperative day in 140 patients. First defecation occurred during hospital stay in 125 patients $(80.6 \%)$. First defecation without pain was reported by 118 of these patients $(76.1 \%)$. Resume of normal activities and/or return to work took place after 3 to 14 days (mean 5.9 days).

Postoperative complications are illustrated in Table 2.

Six patients $(3.9 \%)$, with urinary retention required catheterization. Pain was referred by 37 patients $(23.8 \%)$, and was controlled by standard analgesia in all cases. No cases of chronic pain were detected after 12 weeks.

Fever $\left(>37.8^{\circ} \mathrm{C}\right)$ was observed in three patients $(1.9 \%)$, without any signs of perianal infection but patients were medicated with ciprofloxacin ( $1 \mathrm{~g}$ /day for 5 days). No additional therapy was necessary. After the procedure, three patients referred incontinence for flatus $(1.9 \%)$ and no patients referred incontinence for feces.

Mucous prolapse occurred in five cases $(3.2 \%)$ and treated by rubber band ligation, with satisfactory result. Hemorrhoidal

TABLE 2 - Postoperative complications

\begin{tabular}{lcc}
\hline Complication & Number (n) & $\%$ \\
\hline Bleeding & 16 & 10.3 \\
Tenesmus & 6 & 3.9 \\
Fecal impactation & 2 & 1.9 \\
Urgency & 2 & 1.9 \\
Severe pain (needs opiates) & 5 & 3.2 \\
Urinary retention & 6 & 3.9 \\
Fever & 3 & 1.9 \\
Partial incontinence & 3 & 1.9 \\
Mucous prolapse & 5 & 3.2 \\
Failure of circular stapler & 1 & 0.6 \\
Introduction failure of PPH & 1 & 0.6 \\
Hemorrhoidal thrombosis & 2 & 1.3 \\
Recurrence & 2 & 1.3 \\
\hline
\end{tabular}


thrombosis was observed in two cases $(1.3 \%)$ that required surgical excision. After the stapled hemorrhoidopexy, two patients $(1.3 \%)$ presented symptoms of recurrent hemorrhoidal disease and were successfully treated by conventional hemorrhoidectomy.

Sixteen patients $(10.3 \%)$ referred anal bleeding in the first follow-up visit at postoperative days 5 to 7 . All of these cases were submitted rectosigmoidoscopy. No alterations were detected in 15 patients. Oozing from the anastomosis was observed in one patient and was successfully managed by infiltration of xylocaine with epinephrine and local compression. None of these sixteen subjects required a new surgery or blood transfusion.

There were no cases of anal stenosis, permanent incontinence or deaths in this series.

\section{DISCUSSION}

Pain control after hemorrhoidectomy has always been a major concern for surgeons and represents one of the most feared conditions associated with the surgical treatment of hemorrhoidal disease. A great number of alternative measures have been proposed to reduce postoperative pain without satisfactory results.

Stapled hemorrhoidopexy, as proposed by $\mathrm{LONGO}^{(12)}$ in 1998 , represented a great modification in the treatment of advanced hemorrhoid disease. Its main advantage would be a lower incidence of postoperative pain since the sensitive anal mucosa is not traumatized during the procedure as compared with standard surgical techniques ${ }^{(8,9,15,24)}$

Several randomized trials comparing stapled hemorrhoidopexy with traditional hemorrhoidectomy were developed to test the feasibility and efficacy of the technique ${ }^{(7,9,10,11,16,24)}$.

A systematic review conducted by SUTHERLAND et al. ${ }^{(24)}$ that included seven prospective randomized trials comparing stapled hemorrhoidopexy with conventional hemorrhoidectomy, found strong evidence in favor of the stapled procedure considering length of surgical procedure, anal bleeding during the first 2 weeks and postoperative pain, analgesic consumption, healing and return to normal activities. These results are in agreement with a multicenter study ${ }^{(7)}$ that found a significant reduction in period of hospitalization (mean 1 day vs. 2 days). In this study, $90.3 \%$ of patients were discharged on the first postoperative day. Other interesting finding was that resume of normal activities and return to work took place after 3 to 14 days, with a mean period of 6 days.

A reduction of postoperative pain and need for analgesics are one of the most attractive features of the stapling technique highlighted by many authors ${ }^{(8,9,11,13,15,24)}$. In our series, analgesia has been accomplished with oral medications in $84.5 \%$ that were usually interrupted during the third to fifth postoperative days. This lower incidence of postoperative pain would be a consequence of less surgical trauma to the anal region and a faster healing of surgical wound (4-7 weeks for the conventional technique vs. 1-2 weeks for the stapling technique $)^{(19,24)}$.

HETZER et al. ${ }^{(9)}$ found no difference in the occurrence of recurrent hemorrhoidal disease when comparing the stapled and conventional procedures. However, other authors reported a higher recurrence with the stapled technique specially with fourth degree hemorrhoidal disease ${ }^{(16)}$. We had two cases of recurrence $(1.3 \%)$ - an originally grade IV hemorrhoid - successfully managed with conventional hemorrhoidectomy.

There are reports of perianal infections and sepsis after the stapling technique that have led some authors to propose the use of prophylactic antibiotics ${ }^{(14,16,24)}$. Despite the absence of strong evidence in favor of such measures, all our patients received antibiotic prophylaxis with cefoxitin during anesthetic induction. Three $(1.9 \%)$ patients developed fever in the postoperative period and received ciprofloxacin ( $1 \mathrm{~g} /$ day) despite any evidence of systemic or surgical site infection.

After analysis of the early postoperative results, evaluation of functional results focused on several studies $(7,11,16,19,20)$. Some authors found no difference regarding fecal incontinence when comparing conventional hemorrhoidectomy and stapled hemorrhoidopexy. GANIO et al. (7) $^{(3)}$ observed no difference regarding rest pressure and squeeze pressure in the pre and postoperative period in both groups. SHALABY and DESOKY ${ }^{(19)}$ obtained the same results in the PPH group; however, they found lower rest and squeeze pressures in the postoperative period in the group submitted to conventional hemorrhoidectomy. In our series, we observed three cases of incontinence to gas and no incontinence for solids after at least 14 months of follow-up.

Some surgeons are still afraid of a higher risk of stenosis with PPH. Nevertheless, there is no evidence in the literature to support this statement. In fact, SHALABY and DESOKY ${ }^{(19)}$ reported a stenosis frequency of $2 \%$ in the $\mathrm{PPH}$ group and of $5 \%$ in the conventional hemorrhoidectomy group. Similarly to other series ${ }^{(8,9)}$, no cases of anal stenosis were verified during our follow up.

Long-term evaluation of results and complications of hemorrhoidopexy are still lacking in the literature ${ }^{(17,20)}$. SMYTH et al. ${ }^{(20)}$ published a series of patients submitted to $\mathrm{PPH}$ with a mean follow-up of 37 months and found no significant differences in terms of quality of life, functional outcomes and recurrence (no cases in both groups). In our series, there were six cases of tenesmus, urgency was found in two cases and fecal impactation in another two cases that improved with conservative measures.

The fact that the present study is a prospective non-randomized trial could impose some limitations to our results interpretations. However, as stated above, these results are in agreement to other large prospective randomized and non-randomized trials already published that validate the benefits and restrictions observed with this new technique in the management of advanced hemorrhoids.

\section{CONCLUSION}

In summary and in agreement with other published series, hemorrhoidopexy can be considered an alternative technique with good outcomes for management of advanced hemorrhoid disease for selected patients. In these patients, PPH may be considered a feasible and safe procedure associated with lower postoperative pain, earlier return to normal activity and complication rates similar to the conventional technique. 
Sobrado CW, Cotti GCC, Coelho FF, Rocha JRM. Experiência inicial com o tratamento da doença hemorroidária pela técnica de grampeamento circular. Arq Gastroenterol. 2006;43(3):238-42.

RESUMO - Racional - A introdução por Longo em 1998, da hemorroidopexia pela técnica de grampeamento circular representou uma mudança radical no tratamento cirúrgico da doença hemorroidária, ao passo que propõe o reposicionamento da mucosa anorretal prolapsada, sem excisão do mamilo hemorroidário, cursando assim com menor dor e menor tempo de recuperação pós-operatórios. Objetivo - Apresentar e analisar os resultados intra e pós-operatórios obtidos durante a experiência inicial com a técnica de grampeamento circular. Pacientes $\boldsymbol{e}$ método - Foram incluídos 155 pacientes (67 homens) com média de idade de 39,5 anos (21-67 anos) e doença hemorroidária sintomática grau III $(n=74)$ e IV $(n=81)$, operados consecutivamente pelo método do grampeamento circular entre junho de 2000 e dezembro de 2003. Resultados e complicações pós-operatórias foram aferidos num tempo de seguimento médio de 20 meses (14-60 meses). Resultados - Os principais sintomas pré-operatórios foram prolapso (96,7\%) e sangramento (96,1\%). O tempo operatório médio foi de 23 minutos (16-48 minutos). Houve um caso de falha do equipamento e um de impossibilidade de introdução do mesmo (paciente com cirurgia anal prévia). Hemostasia adicional com sutura foi necessária em 103 pacientes $(66,5 \%)$ e a ressecção de plicomas foi realizada concomitantemente ao procedimento em 45 pacientes (29\%). A analgesia pós-operatória via oral com dipirona e celecoxib foi eficiente no controle da dor em 131 pacientes $(84,5 \%), 24(15,5 \%)$ necessitaram de analgesia complementar, sendo que 5 pacientes receberam opióides devido a dor intensa. A maioria dos pacientes (140 - 90,3\%) teve alta no primeiro dia de pós-operatório e $118(76,1 \%)$ referiram a primeira evacuação sem dor. As complicações pós-operatórias observadas foram: sangramento $(10,3 \%)$, tenesmo $(3,9 \%)$, retenção urinária $(3,9 \%)$, febre sem sinais infecciosos $(1,9 \%)$, incontinência transitória para flatos $(1,9 \%)$ e trombose hemorroidária $(1,3 \%)$. Ocorreram duas recurrências sintomáticas, tratadas com sucesso por hemorroidectomia convencional. Na presente casuística não foram observados casos de estenose, dor crônica, incontinência permanente ou óbito. Conclus̃̃es - O grampeamento circular para o tratamento da doença hemorroidária é técnica segura e factível, representando uma alternativa à hemorroidectomia convencional, para casos selecionados.

DESCRITORES - Complicações pós-operatórias. Cirurgia anorretal. Hemorróidas. Técnicas de sutura. Grampeamento cirúrgico.

\section{REFERENCES}

1. Altomare DF, Rinaldi M, Sallustio PL, Martino P, De Fazio M, Memeo V. Long-term effects of stapled haemorrhoidectomy on internal anal function and sensitivity. $\mathrm{Br} J$ Surg. 2001;88:1487-91.

2. Borba MR, Sobrado CW, Sokol S. Hemorroidectomia pela técnica fechada (técnica de Sokol). Análise de 322 doentes. Rev Bras Coloproctol. 1997;17:98-100.

3. Carapeti EA, Kamm MA, McDonald PJ, Phillips RK. Double-blind randomized controlled trial of effect of metronidazole on pain after day-case haemorrhoidectomy. Lancet. 1998:351:169-72.

4. Cheetam MJ, Mortensen NJ, Nystron PO, Kamm MA, Phillips RK. Persistent pain and faecal urgency after stapled haemorrhoidectomy. Lancet. 2000;356:730-3.

5. Corman ML, Gravie JF, Hager T, Loudon MA, Mascagni D, Nystrom PO, Seow-Choen F, Abcarian H, Marcello P, Weiss E, Longo A. Stapled hemorrhoidopexy: a consensus position paper by an international working party - indications, contra-indications and technique. Colorectal Dis. 2003;5:304-10.

6. Fazio VW. Early promise of stapling technique for haemorrhoidectomy. Lancet 2000;355:768-9.

7. Ganio E, Altomare DF, Gabrielli F, Milito G, Canuti S. Prospective randomized multicentre trial comparing stapled with open hemorrhoidectomy. Br J Surg. 2001;88:669-74.

8. Habr-Gama A, Silva-e-Sousa Jr AH, Rovelo JMC, Souza JS, Benício F, Regada FSP, Wainstein C, Cunha TMR, Marques CFS, Bonardi RA, Ramos JR, Pandini LC, Kiss DR. Stapled hemorrhoidectomy: initial experience of a Latin American group. J Gastrointest Surg. 2003;7:809-13.

9. Hetzer FH, Demartines N, Handschin AE, Clavien PA. Stapled vs excision hemorrhoidectomy long-term results of a prospective randomized trial. Arch Surg. 2002;137:337-40.

10. Ho YH, Seow-Choen F, Tsang C, Eu KW. Randomized trial assessing sphincter injurie after stapled hemorrhoidectomy. Br J Surg. 2001;88:1449-55.

11. Khalil KH, O'Bichere A, Sellu D. Randomized clinical trial of sutured versus stapled closed hemorrhoidectomy. Br J Surg. 2000;87:1352-5.

12. Longo A. Treatment of hemorrhoidal disease by reduction of mucosa and hemorrhoida prolapse with a circular-suturing device: a new procedure. In: Proceedings of the $6^{\text {th }}$ World Congress of Endoscopic. Rome, Italy: Surgery; 1998.

13. Mehigan BJ, Monson JR, Hartley JE. Stapling procedure for haemorrhoids versus MilliganMorgan haemorrhoidectomy: randomized controlled trial. Lancet. 2000;355:782-5.
14. Molloy RG, Kingsmore D. Life threatening pelvic sepsis after stapled haemorrhoidectomy. Lancet. 2000;355:810

15. Nahas SC, Borba MR, Brochado MCT, Marques CFS, Nahas CSR, Miott-Neto B. Stapled hemorrhoidectomy for the treatment of hemorrhoids. Arq Gastroenterol. 2003;40:35-9.

16. Ortiz H, Marzo J, Armendariz P. Randomized clinical trial of stapled hemorrhoidopexy versus conventional diathermy hemorrhoidectomy. Br J Surg. 2002;89:1376-81.

17. Pernice LM, Bartalucci B, Bencini L, Borri A, Catarzi S, Kröning K. Early and late (ten years) experience with circular stapled hemorrhoidectomy. Dis Colon Rectum. 2001;44:836-41.

18. Ravo B, Amato A, Bianco V, Boccasanta P, Bottini C, Carriero A, Milito G, Dodi G, Mascagni D, Orsini S, Pietroletti R, Ripetti V, Tagariello GB. Complications after stapled hemorrhoidectomy: can they be prevent ? Tech Coloproctol. 2002;6:83-8.

19. Shalaby R, Desoky A. Randomized clinical trial of stapled versus Milligan-Morgan hemorrhoidectomy. Br J Surg. 2001;88:1049-53.

20. Smyth EF, Baker RP, Wilken BJ, Hartley JE, White TJ, Monson JR. Stapled versus excision haemorrhoidectomy: long-term follow-up of a randomized controlled trial. Lancet. 2003;361:1437-8.

21. Sobrado CW, Bringel RWA, Nahas SC. Tratamento cirúrgico da doença hemorroidária. In: Cruz GMG, editor. Coloproctologia terapêutica. Rio de Janeiro: Revinter; 2000. v.3, p.2148-60

22. Sobrado CW. Doença hemorroidária. In: Silva JH, editor. Manual de coloproctologia. São Paulo: Zeppelini; 2000. p.137-50.

23. Sobrado CW. Tratamento cirúrgico da doença hemorroidária. In: Silva JH, editor Manual de coloproctologia. São Paulo: Zeppelini; 2000. p.151-74.

24. Sutherland LM, Burchard AK, Matsuda K, Sweeney JL, Bokey EL, Childs PA, Roberts AK, Waxman BP, Maddern GJ. A systematic review of stapled hemorrhoidectomy. Arch Surg. 2002;137:1395-406.

25. Wexner SD. The quest for painless surgical treatment of hemorrhoids continues. J Am Coll Surg. 2001:193:174-8. 